\title{
Modelling and analyzing the watershed dynamics using Cellular Automata (CA)-Markov model - A geo-information based approach
}

\author{
Mukunda D Behera, ${ }^{1, *}$ Santosh N Borate ${ }^{2}$, Sudhindra N Panda ${ }^{2}$, \\ Priti R BeherA ${ }^{2}$ and PARThA S ROY ${ }^{3}$ \\ ${ }^{1}$ Centre for Oceans, Rivers, Atmosphere and Land Sciences (CORAL), \\ Indian Institute of Technology, Kharagpur 721 302, India. \\ ${ }^{2}$ School of Water Resources, Indian Institute of Technology, \\ Kharagpur 721 302, India. \\ ${ }^{3}$ Indian Institute of Remote Sensing (ISRO), Dehradun 248 001, India. \\ *Corresponding author.e-mail: mukundbehera@gmail.com
}

\begin{abstract}
Improper practices of land use and land cover (LULC) including deforestation, expansion of agriculture and infrastructure development are deteriorating watershed conditions. Here, we have utilized remote sensing and GIS tools to study LULC dynamics using Cellular Automata (CA)-Markov model and predicted the future LULC scenario, in terms of magnitude and direction, based on past trend in a hydrological unit, Choudwar watershed, India. By analyzing the LULC pattern during 1972, 1990, 1999 and 2005 using satellite-derived maps, we observed that the biophysical and socio-economic drivers including residential/industrial development, road-rail and settlement proximity have influenced the spatial pattern of the watershed LULC, leading to an accretive linear growth of agricultural and settlement areas. The annual rate of increase from 1972 to 2004 in agriculture land, settlement was observed to be 181.96, 9.89 ha/year, respectively, while decrease in forest, wetland and marshy land were 91.22, 27.56 and $39.52 \mathrm{ha} /$ year, respectively. Transition probability and transition area matrix derived using inputs of (i) residential/industrial development and (ii) proximity to transportation network as the major causes. The predicted LULC scenario for the year 2014, with reasonably good accuracy would provide useful inputs to the LULC planners for effective management of the watershed. The study is a maiden attempt that revealed agricultural expansion is the main driving force for loss of forest, wetland and marshy land in the Choudwar watershed and has the potential to continue in future. The forest in lower slopes has been converted to agricultural land and may soon take a call on forests occurring on higher slopes. Our study utilizes three time period changes to better account for the trend and the modelling exercise; thereby advocates for better agricultural practices with additional energy subsidy to arrest further forest loss and LULC alternations.
\end{abstract}

\section{Introduction}

Today, there is increased recognition that land use and land cover change (LULCC) is a major driver of global change, through its interaction with climate, ecosystem processes, biogeochemical cycles, biodiversity and even more importantly the human activities (NRC 1999). In the last two decades,

Keywords. Land use; classification; Choudwar; transition probability; transition area matrix. 
the magnitude and spatial reach of human impacts on the earth's land surface is unprecedented (Lambin et al. 2001). Changes in land cover (biophysical attributes of the earth's surface) and land use (human modified earth's surface) has been accelerating as a result of socio-economic and biophysical drivers (Turner et al. 1995; Lambin et al. 1999) and are closely linked with the issue of the sustainability of socio-economic development since they affect essential parts of our natural capital such as vegetation, water resources and biodiversity (Mather and Sdasyuk 1991). Improper practices of LULC including deforestation, uncontrolled and excessive grazing, expansion of agriculture, and infrastructure development are deteriorating watershed conditions (Bishaw 2001), at various temporal and spatial scales (Bisht and Tiwari 1996). The analysis and modelling of LULC dynamics in a hydrological unit of a watershed provides understanding in totality. It is a two-way process when LULCC in watershed changes the performance characteristics of watershed which includes the water infiltration rate, soil erosion rate, runoff, etc., and vice versa (Zhang et al. 2007).

A decision-maker will be interested to know; what and where changes have occurred, and also why such changes happened, at what pace such change will happen, and what it will look like if the driving factors continue to function in the same or alternative way. The answer to these questions lies on a reliable LULCC model, which aims at predicting the spatial distribution of the specific LULC classes in a later year by utilizing the knowledge gained from previous years. Among the numerous efforts developed in this category, the spatial transition-based models, i.e., Markov Chain model and Cellular Automata (CA) model have played a central role. Markov chain is one of the most accepted method for modelling LULCC using current trends; because it uses evolution from ' $t-1$ ' to ' $t$ ' to project probabilities of land use changes for a future date ' $t+1$ ' (Thomas and Laurence 2006). The method is based on probability that a given piece of land will change from one mutually exclusive state to another (Thomas and Laurence 2006). These probabilities are generated from past changes and then applied to predict future change. However, a stochastic Markov model is not appropriate because it does not consider spatial knowledge distribution within each category and transition probabilities are not constant among landscape states; so it may give the right magnitude of change but not the right direction (Boerner et al. 1996). In a Markov process, there is a discrete set of states $S$. In each state, there are a number of possible events that can cause a transition. The event that causes a transition from state $i$ to $j$, where $j 6=i$, takes place after an exponential amount of time, say with parameter qij. As a result, in this model transitions take place at random points in time. Cellular Automata (CA) incorporates the spatial component (Soe and Le 2006) and thereby adds direction to modelling. It has the ability to change its state, based on a rule that relates the new state to the previous state and those of its neighbours (Clarke and Gaydos 1998). It is implemented in LULC models that are able to simulate multiple land use types (Thomas and Laurence 2006). Hence, Cellular Automata Markov (CA-Markov) allows any number of categories and can simulate the transition from one category to another.

CA-Markov is an interesting approach to model both spatial and temporal changes:

- the Markov process controls temporal dynamics among the LULC types through the use of transition probabilities,

- spatial dynamics are controlled by local rules through a CA mechanism considering either neighbourhood configuration and transition probabilities (Sylvertown et al. 1992),

- GIS and remotely sensed data is used to define initial conditions, to parameterize CA-Markov model, to calculate transition probabilities and to determine the neighbourhood rules (Wang and Zhang 2001).

Soe and Le (2006) used multi-criteria decision making (MCE) technique for LULC change detection and for prediction of future scenarios in which decision of land allocations was done by considering the different criteria. The criteria development depends upon the weight allocation to the LULC changing drivers; more the relative importance of driver, higher the weight allocated to the driver in criterion development (Malczewski 1999). Here, we have analyzed and modelled the LULCC with CA-Markov model by considering the biophysical and socio-economic drivers in Choudwar watershed falling in Mahanadi river basin, India. Change detection of LULC was done by using multi-date images for the year 1972, 1990, 1999 and 2004. The final results of prediction showed the CA-Markov usefulness to build more plausible future states in different scenarios of LULC change with influence of different biophysical and socio-economic drivers, and their relative importance in LULC change in watershed through the utility of remote sensing and GIS tools.

\section{Methodology}

\subsection{Study area}

Choudwar watershed, the study area chosen is located at the north side of Cuttack city, Odisha, 
India falls in delta of Mahanadi river basin (figure 1). The geographical boundary of the catchment lies between latitude $20^{\circ} 29^{\prime} 33^{\prime \prime}-20^{\circ} 40^{\prime} 21^{\prime \prime} \mathrm{N}$ and longitude $85^{\circ} 44^{\prime} 59.33^{\prime \prime}-85^{\circ} 54^{\prime} 16.62^{\prime \prime} \mathrm{E}$. The drainage area of the watershed is about $196 \mathrm{~km}^{2}$. It is bounded by Mahanadi river at south side and the Kapilas hill ranges with reserved forest on the north side while the Choudwar industrial area on east side and Dhenkanal district boundary on west side. It comprises of varied LULC including forest land, agriculture land, marshy land, wetland, fallow and barren land; and proximity to Choudwar industrial area. Much of the forests and wetlands, however, have been removed as a result of agricultural expansion and residential area development.

\subsection{Satellite data: Mapping and change}

In this study, we selected one Landsat MSS, two Landsat TM and one Landsat ETM+ images pertaining to the years 1972, 1990, 1999 and 2004 for LULC mapping (table 1). Coincidentally, all the images belonged to the month of November. The study area was extracted from the acquired satellite images using watershed boundary generated from SRTM DEM using the Arc hydro tool in ArcGIS. We used UTM coordinate system with zone 45 north and datum WGS for satellite imagery registration. A classification scheme was developed to obtain a broad level of classification, to derive various LULC classes, i.e., agriculture, settlement, forest, wetland, marshy land,

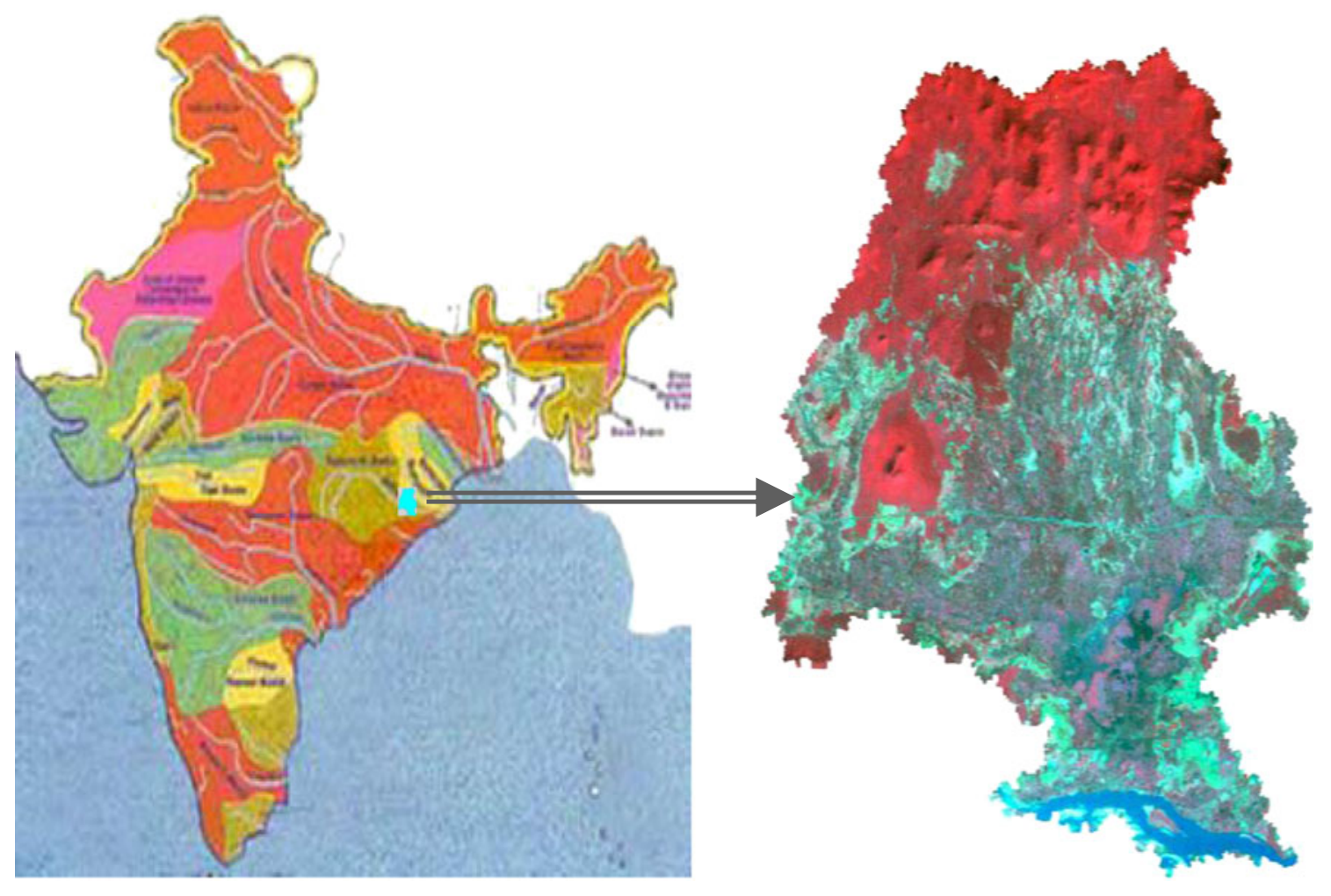

Figure 1. Location map of the study area, Choudwar watershed.

Table 1. Satellite data specifications.

\begin{tabular}{|c|c|c|c|c|c|}
\hline Year & Satellite & $\begin{array}{l}\text { Resolution } \\
\text { (m) }\end{array}$ & Path/row & $\begin{array}{c}\text { Band } \\
\text { combination }\end{array}$ & $\begin{array}{c}\text { Date of } \\
\text { procurement }\end{array}$ \\
\hline 1972 & Landsat, MSS & 79 & $150 / 46$ & $1,2,3,4$ & 7 November 1972 \\
\hline 1990 & Landsat, TM & 30 & $140 / 46$ & $1,2,3,4,5,7$ & 28 November 1990 \\
\hline 1999 & Landsat, $\mathrm{ETM}^{+}$ & 30 & $140 / 46$ & $1,2,3,4,5,7$ & 29 November 1999 \\
\hline 2004 & Landsat, TM & 30 & $140 / 46$ & $1,2,3,4,5,7$ & 2 November 2004 \\
\hline
\end{tabular}



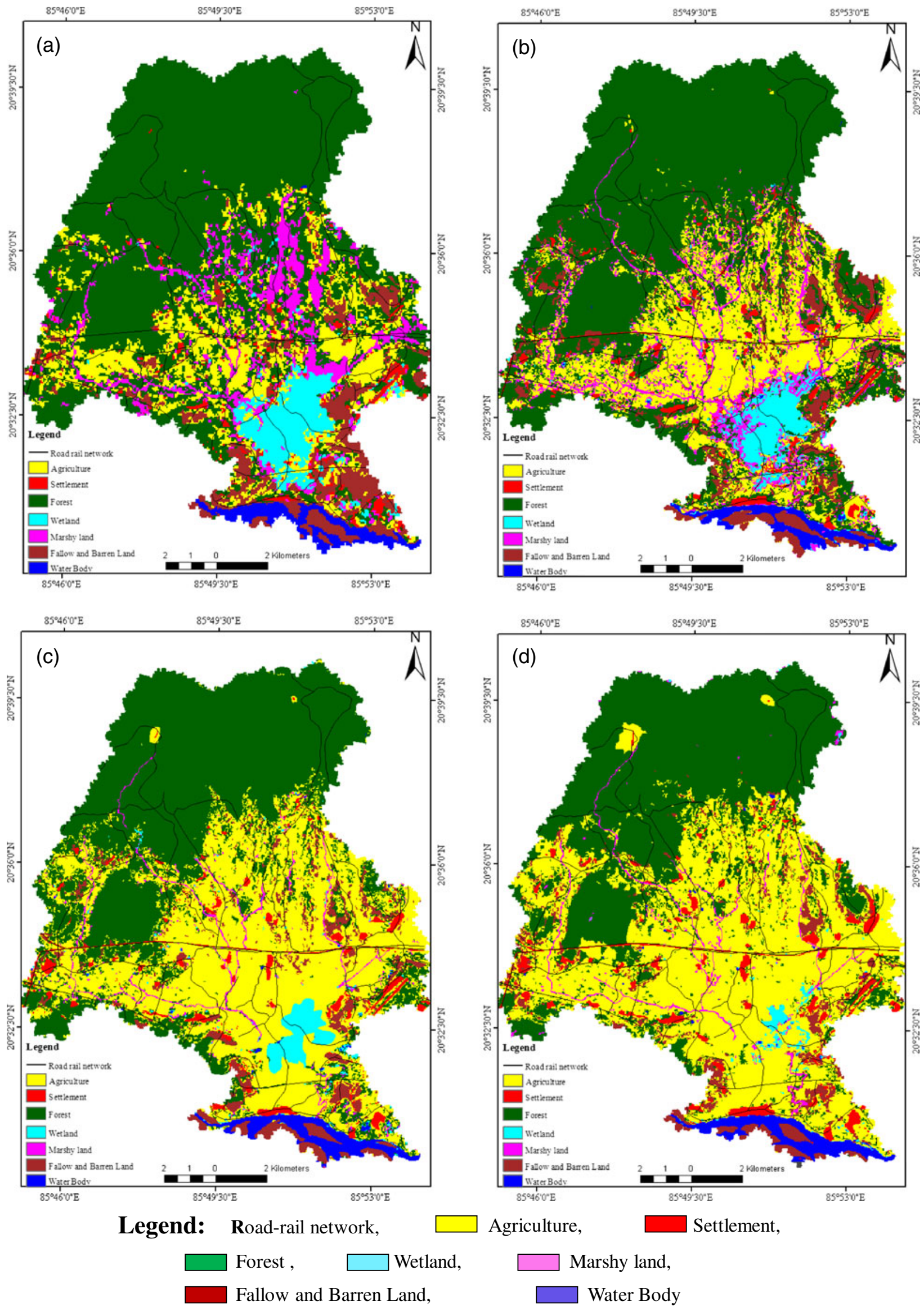

Agriculture, $\square$ Settlement,

$\square$ Marshy land,

Water Body

Figure 2. Land use land cover classification for years (a) 1972, (b) 1990, (c) 1999 and (d) 2004. 
Table 2. Socio-economic and physiognomic data utilized.

\begin{tabular}{|c|c|c|c|}
\hline Sl. no. & Data type & Year & Source \\
\hline \multicolumn{4}{|c|}{ Socio-economic } \\
\hline $1 \mathrm{H}$ & Population & $1971,1981,1991,2002$ & Census of India \\
\hline 2 & Residential development & $1971,1981,1991,2002$ & Statistical handbook \\
\hline 3 & Industrial development & $1991,2001,2004,2007$ & Statistical handbook \\
\hline 4 & Road network & & Topomap and reference map \\
\hline 5 & Railway network & & Topomap and reference map \\
\hline 6 & Total area under winter crops & $1991,2001,2004$ & Statistical handbook \\
\hline \multicolumn{4}{|c|}{ Physiognomic } \\
\hline $1 \mathrm{I}$ & Drainage network & & ASTER DEM \\
\hline 2 & Slope & & ASTER DEM \\
\hline
\end{tabular}

Table 3. LULC distribution for years 1972, 1990, 1999 and 2004.

\begin{tabular}{|c|c|c|c|c|}
\hline Year & 1972 & 1990 & 1999 & 2004 \\
\hline LULC class & Area $(\text { ha })^{*}$ & Area $($ ha $)(*)$ & Area (ha) $(*)$ & Area (ha) $(*)$ \\
\hline Agriculture & $3055(15.35)$ & $4500.03(22.82)$ & $8194(41.57)$ & $8878(44.93)$ \\
\hline Settlement & $422(2.12)$ & $549.73(2.79)$ & $575.9(2.92)$ & $738.63(3.74)$ \\
\hline Forest & $11608(58.35)$ & $10182(54.86)$ & $8624(43.76)$ & $8098(40.98)$ \\
\hline Wetland & $1043(5.24)$ & $693.17(3.52)$ & $430(2.18)$ & $160.92(0.81)$ \\
\hline Marshy land & $1578(7.93)$ & $1427.29(7.24)$ & $331.3(1.68)$ & $313.29(1.59)$ \\
\hline Fallow and barren land & $1749(8.79)$ & $1354.51(6.87)$ & $1124(5.70)$ & $1119(5.66)$ \\
\hline Water & $442(2.22)$ & $377.29(1.91)$ & $430.9(2.19)$ & $451(2.28)$ \\
\hline
\end{tabular}

*Percentage area is given in parenthesis.

fallow and barren land and water body (figure 2). The field visits were made to complete reconnaissance survey, ancillary data collection and LULC classification and validation (tables $2,3,4,5$ ). LULC classification was performed using unsupervised classification technique for years 1972, 1990, 1999 and 2004 (figures 2, 3). An unsupervised classification approach allows the spectral clustering which gives high degree of objectivity (Yang and Lo 2002). Classification accuracy assessment was performed for each LULC maps based on the collected GCPs (Ground Control Points) using GPS, and additional information from Google Earth. In this context, multi-date images were collected along with field investigations and socio-economic statistical data since 1972 . The spatial layers of ancillary database including different socioeconomic and biophysical drivers of LULC change were prepared using data from Indian census, statistical handbook and NRIS (table 2). CAMarkov model was employed to predict future LULC dynamics in the watershed using a multicriteria decision-making approach. This task was accomplished by using IDRISI software package developed in Clark Labs, Worcester, Mass.

\subsection{Multi-criteria evaluation (MCE) technique}

It is impossible to find a single solution that can fulfill all of the objectives simultaneously for multiple objective problems of watershed. The decisions that we need to take in general include site selection or land allocation decisions that satisfy multiple objectives, each relating to its own suitability level of land conversion (Soe and Le 2006). To achieve the said objective, multi-criteria evaluation approach was adopted, that deals with situations in which a single decision-maker is faced with a multiplicity of usually incompatible criteria or in which a number of decision-makers must consider criteria, each of which depends on the decisions of all the decision-makers (Ademiluyi and Otun 2009). Here, we integrated socioeconomic data with biophysical data of watershed through multi-criteria evaluation (MCE) technique and CA-Markov. To use MCE technique, there is need to develop criteria for making decision about various land uses.

\subsubsection{Criterion development: Constraints and factors}

We considered different criteria to determine which LULC classes of watershed are suitable for changing from one class to another with time including proximity from road-rail network and settlement; socio-economic drivers, biophysical drivers. In this study, we divided these criteria into different types: factors and constraints, and can pertain either to attributes of the individual or to an entire decision set. 
Table 4. Accuracy assessment of classified LULC maps for the years 1972, 1990, 1999 and 2004.

\begin{tabular}{|c|c|c|c|c|c|c|c|c|}
\hline \multirow[b]{2}{*}{ Class name } & \multicolumn{2}{|c|}{1972} & \multicolumn{2}{|c|}{1990} & \multicolumn{2}{|c|}{1999} & \multicolumn{2}{|c|}{2004} \\
\hline & $\begin{array}{l}\text { Producers } \\
\text { accuracy }\end{array}$ & $\begin{array}{c}\text { Users } \\
\text { accuracy }\end{array}$ & $\begin{array}{l}\text { Producers } \\
\text { accuracy }\end{array}$ & $\begin{array}{c}\text { Users } \\
\text { accuracy }\end{array}$ & $\begin{array}{l}\text { Producers } \\
\text { accuracy }\end{array}$ & $\begin{array}{c}\text { Users } \\
\text { accuracy }\end{array}$ & $\begin{array}{l}\text { Producers } \\
\text { accuracy }\end{array}$ & $\begin{array}{c}\text { Users } \\
\text { accuracy }\end{array}$ \\
\hline Agriculture & 80 & 100 & 90.9 & 90.9 & 94.7 & 85.7 & 95.7 & 95.7 \\
\hline Settlement & 100 & 100 & 100 & 100 & 100 & 100.0 & 100 & 100 \\
\hline Forest & 96.4 & 93.1 & 89.7 & 96.3 & 87.5 & 91.3 & 91.7 & 91.7 \\
\hline Wetland & 100 & 100 & 100 & 100 & 100 & 100 & 100 & 100 \\
\hline Marshy land & 100 & 75 & 100 & 75.0 & 100 & 100 & 100 & 100 \\
\hline $\begin{array}{l}\text { Fallow and } \\
\text { barren land }\end{array}$ & 75 & 75 & 100 & 75 & 50 & 100 & 75 & 75 \\
\hline Water body & 100 & 100 & 100 & 100 & 100 & 100 & 100 & 100 \\
\hline Year & & & & 1972 & 1990 & 1999 & \multicolumn{2}{|l|}{2004} \\
\hline \multicolumn{3}{|c|}{ Overall classification accuracy (\%) } & & 92 & 92 & 90 & 92.3 & \\
\hline \multicolumn{3}{|c|}{ Overall kappa statistics } & & 0.873 & 0.872 & 0.838 & \multicolumn{2}{|c|}{0.893} \\
\hline
\end{tabular}

Here, three constraints were considered, existing settlement, river course and road and railway network. Since new developments cannot usually come-up on river beds, existing settlement, and on road-rail networks, these classes were put under constraints for LULC change (figure 3). The river course considered as a constraint for all the LULC classes except water body. The constraint images for river course, existing settlement and existing road-rail network were expressed in the form of a Boolean (logical) map in which areas excluded from consideration being coded with a zero and those open for consideration being coded with one (Kallali et al. 2006) as shown in figure 3 (e and f). These constraint images were further added up to produce a single image of suitability for each land class.

We attributed nine different factors as driving forces or decision variables for LULC change, viz., proximity to road-rail network, settlement, population, residential development, industrial development, slope, agricultural expansion, drainage network and associated LULC classes. These factors served as criteria that defined some degree of suitability for an activity under consideration and accordingly individual factor scores were assigned. Individual factor scores either enhanced or weakened the overall suitability of an alternative, depending on the relative importance factor (Soe and Le 2006). In this study, criteria used might be complex as threshold applied to a multiple criterion such as, all regions with slopes more than $15 \%$ were considered as non-suitable for new settlement. Areas with settlement distance within $300 \mathrm{~m}$ and road-rail network distance from 50 to $200 \mathrm{~m}$ are more suitable for new settlement (Liang and Ding 2006) which involved the comparison of several multi-criteria evaluations.

The different factors and constraint criteria for different class' suitability

- For agricultural suitability

Factors: slope $<15 \%$, settlement distance $>100 \mathrm{~m}$, population $>25$, residential development $>6$.

Table 5. Area estimates of LULC change in the watershed ('percentage area); '-' sign indicates decrease in area.

\begin{tabular}{|c|c|c|c|c|}
\hline \multirow[b]{2}{*}{ LULC class } & \multicolumn{3}{|c|}{ Change area (in ha)* } & \multirow{2}{*}{$\begin{array}{l}\begin{array}{c}\text { Annual rate of } \\
\text { change (ha/year }\end{array} \\
1972-2004\end{array}$} \\
\hline & $1972-1990$ & 1990-1999 & 1999-2004 & \\
\hline Agriculture & $1445.03(47.3)$ & $3694.38(82.1)$ & $683.59(8.34)$ & 181.96 \\
\hline Settlement & $127.73(30.27)$ & $26.18(4.76)$ & $162.72(28.25)$ & 9.89 \\
\hline Forest & $-790.68(-14.62)$ & $-2194.2(-43.38)$ & $-871(-9.27)$ & -91.22 \\
\hline Wetland & $-349.83(-33.54)$ & $-263.17(-37.97)$ & $-269.08(-62.58)$ & -27.56 \\
\hline Marshy land & $-150.71(-9.55)$ & $-1096.0(-76.79)$ & $-18.00(-5.43)$ & -39.52 \\
\hline $\begin{array}{l}\text { Fallow and } \\
\text { barren land }\end{array}$ & $-394.49(-22.56)$ & $-230.68(-17.03)$ & $-4.83(-0.43)$ & -19.68 \\
\hline Water body & $-64.71(-14.64)$ & $53.63(14.21)$ & $20.08(4.66)$ & -0.28 \\
\hline
\end{tabular}


(a)

(c)
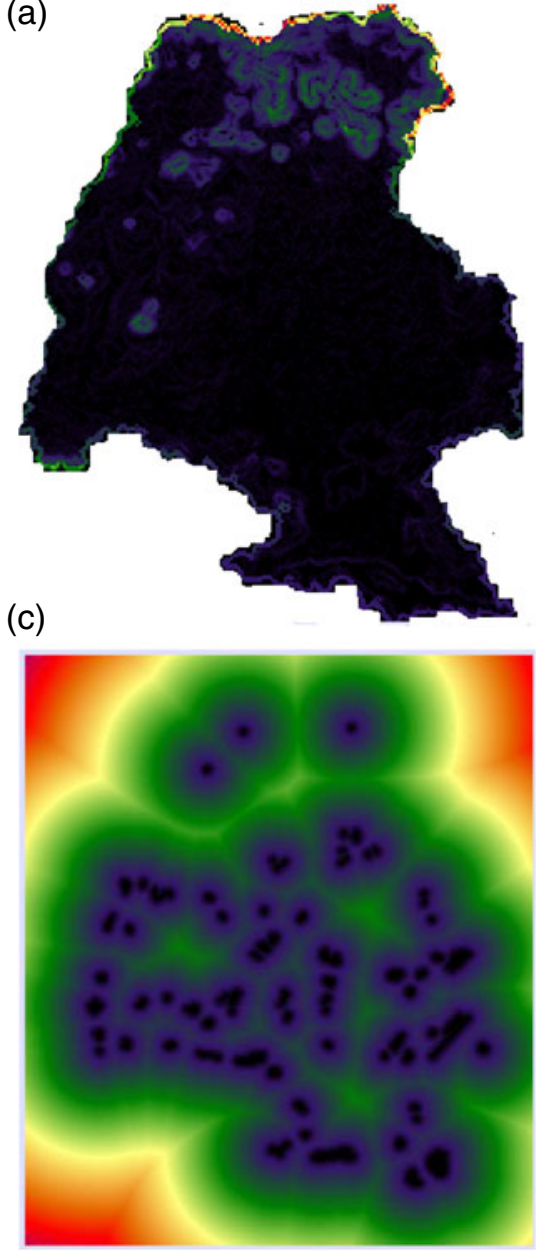

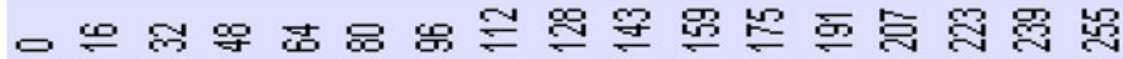
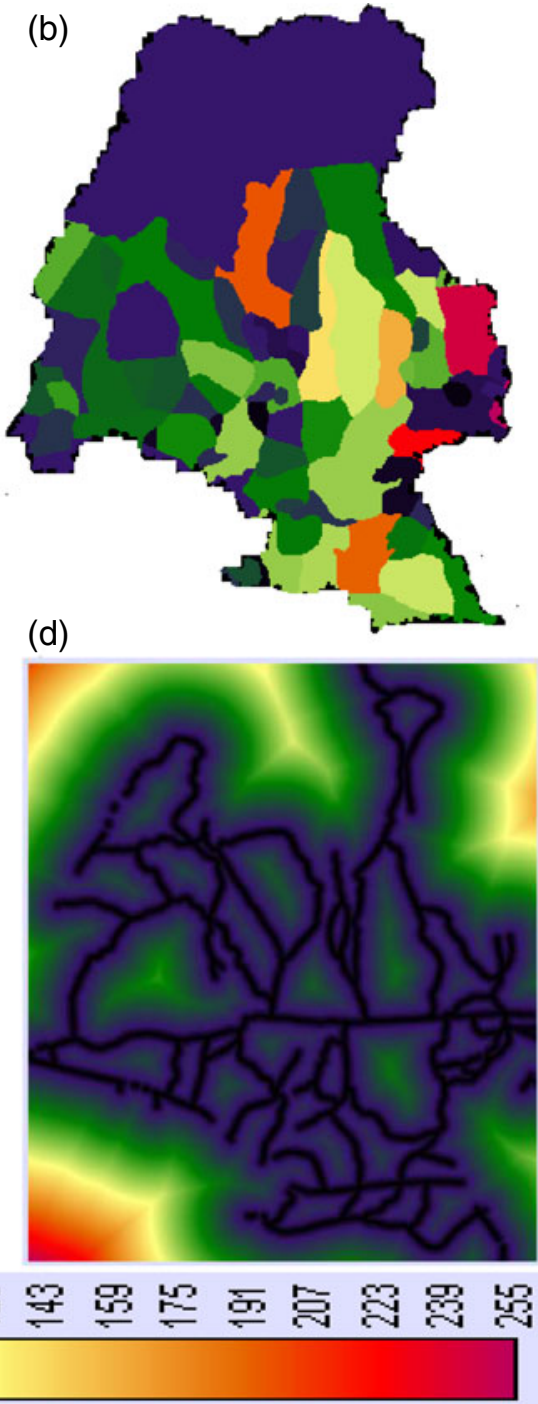

(f)
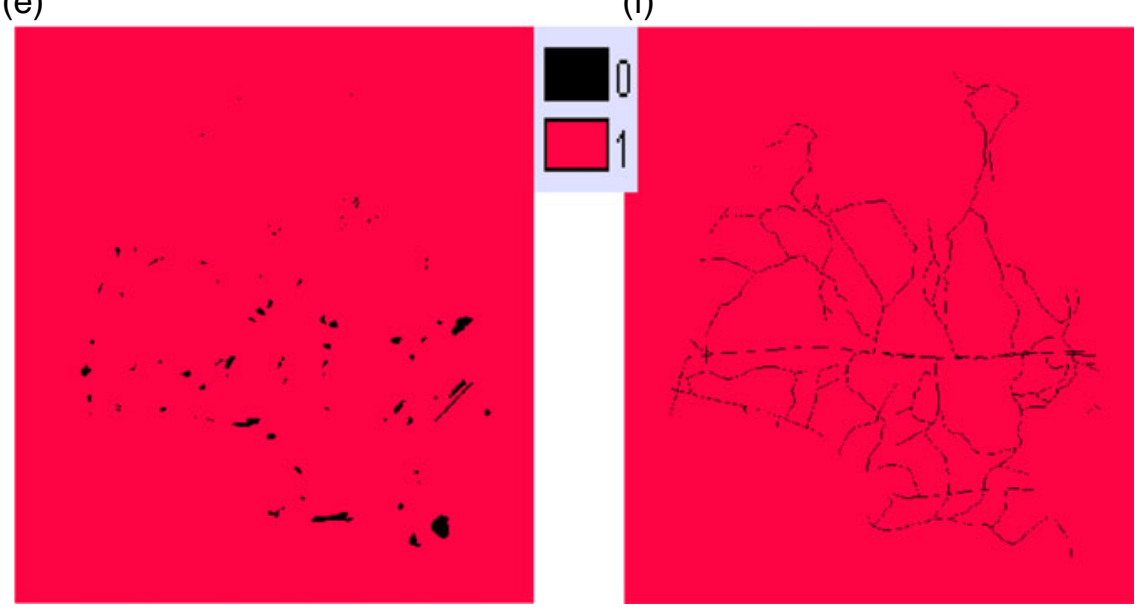

Figure 3. Watershed LULC change drivers (a) slope \%, (b) population, (c) distance from road-rail network; and (d) distance from settlement and constraints, (e) existing settlement, and (f) existing road-rail network.

Constraints: river course, road-rail network and existing settlement.

- For forest suitability
Factors: road rail network distance $>1000 \mathrm{~m}$, slope $2-65 \%$, settlement distance $>4000 \mathrm{~m}$, population $<200$, residential development $<50$. 
Constraints: existing agriculture area, river course, road-rail network and existing settlement.

- For settlement suitability

Factors: settlement distance $>400 \mathrm{~m}$, road-rail network distance $20-500 \mathrm{~m}$, slope $<15 \%$, population $<150$, residential development $<30$.

Constraints: existing settlement, river course and road-rail network.

- For wetland suitability

Factors: slope $<1 \%$, settlement distance $>4000 \mathrm{~m}$, population $<100$, residential development $<20$.

Constraints: existing agriculture area, river course, road-rail network and existing settlement.

- For marshy land suitability

Factors: drainage distance $<5 \mathrm{~m}$, slope $<1-2 \%$, population $<100$.

Constraints: river course, road-rail network and existing settlement, existing agriculture area.

- For fallow and barren land suitability

Factors: slope $<10 \%$, settlement distance 10 $500 \mathrm{~m}$, population $<1000$, residential development $<200$.

Constraints: river course, road-rail network and existing settlement.

- For water body suitability

Factors: slope $<1 \%$, drainage distance $5-15 \mathrm{~m}$, population 100-1000, residential development $<30-200$.

Constraints: road-rail network and existing settlement.

\subsubsection{AHP and fuzzy standardization of factors}

We used MCE process that involves criteria of varying importance in accordance to decision makers and information about the relative importance of the criteria. This is usually obtained by assigning a weight to each factor. Here, agriculture suitability map was prepared by assigning weights for factors like population, residential development, settlement distance and slope as $0.184,0.206,0.567$ and 0.044 , respectively. The larger the weight, the more important is the criterion in the overall utility (Malczewski 1999). The weights assigned to different factors were obtained by analytical hierarchy process (AHP).

To provide a systematic procedure for developing factor weights, we used AHP in which a pairwise comparison matrix created by setting out one row and one column for each factor (Satty and Vargas 2001). Since the matrix is symmetrical, only the lower triangular half actually filled in (figure 4). In developing the weights, an individual factor compared with every other possible pairing, entered the ratings into a pairwise comparison matrix. To illustrate this process, first few ratings were considered. It was observed that settlement distance was very important than slope, and thus received a rating of 7 (figure 4). Importance of settlement distance relative to other factors such as population, roadrail network distance and residential development were rated to the relative significance of strongly important (4), moderately important (6) and more important (3), respectively. The next ratings were then based on the second column as shown in figure 4. This procedure then continued until all of the cells in the lower triangular half of the matrix were filled. The final factor weights obtained were assigned to specify the relative importance of each factor in determining the aggregate output value.

The final weights generated were not applied to the factor images as a whole; rather they were applied 'pixel by pixel' in the order of suitability scores. The final maps of continuous suitability were the result of criteria aggregation using an operation that is said to be exactly halfway between the AND and OR operations. In this study, Weighted Linear Combination (WLC) method was used for aggregation of parameters.

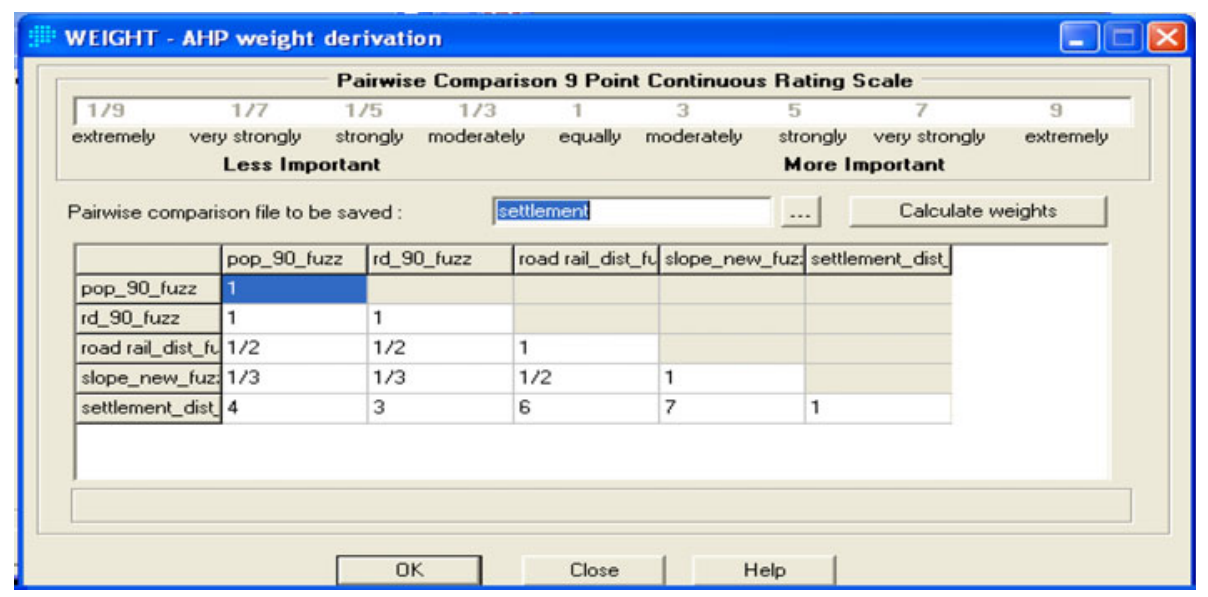

Figure 4. Pairwise comparison approach to derive the factor weights. 

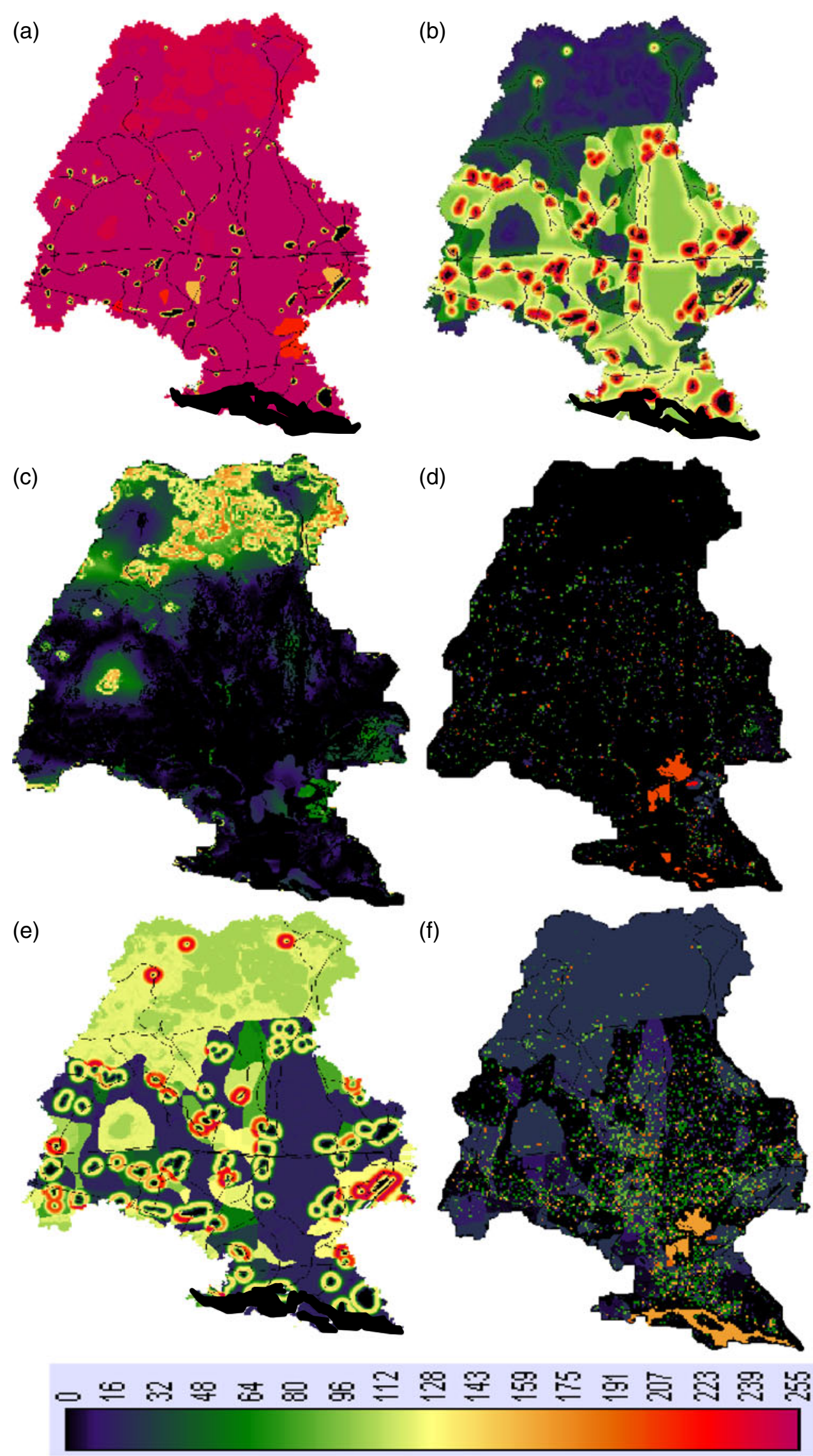

Figure 5. Suitability maps for (a) agriculture, (b) settlement, (c) forest, (d) wetland (e) barren and fallow land and (f) water body. 
Table 6. Transition area matrix for prediction of LULC in year 2004 by using LULC images of 1990 and 1999.

\begin{tabular}{lccccccc}
\hline $\begin{array}{l}\text { LULC } \\
\text { classes }\end{array}$ & Agriculture & Settlement & Forest & Wetland & $\begin{array}{c}\text { Marshy } \\
\text { land }\end{array}$ & $\begin{array}{c}\text { Fallow and } \\
\text { barren land }\end{array}$ & $\begin{array}{l}\text { Water } \\
\text { body }\end{array}$ \\
\hline Agriculture & 67984 & 2875 & 6842 & 581 & 3010 & 6264 & 0 \\
Settlement & 2092 & 3466 & 399 & 22 & 90 & 264 & 0 \\
Forest & 21976 & 1576 & 70953 & 269 & 781 & 3005 & 100 \\
Wetland & 1930 & 0 & 45 & 2602 & 68 & 0 & 34 \\
Marshy land & 2450 & 58 & 392 & 83 & 627 & 5 & 779 \\
$\begin{array}{l}\text { Fallow and } \\
\quad \text { barren land }\end{array}$ & 2523 & 419 & 2460 & 32 & 12 & 6090 & 3527 \\
$\quad$ & & & & & & & \\
Water body & 111 & 2 & 0 & 135 & 34 & 940 & 3527 \\
\hline
\end{tabular}

Table 7. Continuous rating scale.

\begin{tabular}{cccc|c|cccc}
\hline $1 / 9$ & $1 / 7$ & $1 / 5$ & $1 / 3$ & 1 & 3 & 5 & 7 & 9 \\
\hline Extremely & Very strongly & Strongly & Moderately & Equally & Moderately & Strongly & Very strongly & Extremely \\
\hline & Less important & & $\begin{array}{c}\text { Equally } \\
\text { important }\end{array}$ & & \multicolumn{3}{c}{ More Important } \\
\hline
\end{tabular}

This process carries the lowest possible risk as the areas considered suitable are those considered suitable with all criteria fulfilled. The effect of 'order of weights' is most easily understood in terms of levels of risk and trade off. It was neither extremely risk-averse nor extremely risk-taking (Soe and Le 2006). Any factor could compensate for any other according to its factor weight. At both extremes of the continuum, tradeoff is not possible, but in the middle there is the potential for full trade off. Here, the suitability of areas were determined with consideration of drivers or factors, i.e., population, residential development, slope, drainage network, distance from settlement and distance from roadrail network. The suitability map for each LULC class in watershed was prepared with different criteria and relative weights (figure 5).

\subsubsection{Markov chain and cellular automata}

A Markovian process is one in which the state of a system at time $\left(t_{2}\right)$ can be predicted by the state of the system at time $\left(t_{1}\right)$ (Thomas and Laurence 2006). In this study, Markovian process was used to obtain a transition area matrix from transition probability matrix. In a transition probability matrix, the transition probabilities express the likelihood that a pixel of a given class will change to any other class (or stay the same) in the next time period. It is a text file that records the probability that each LULC category will change to every other category. A transition area matrix expresses the total area (in cells) expected to change in the next time period. It is also a text file that records the number of pixels that are expected to change from one LULC type to other over the specified number of time units. It is produced by multiplication of each column in transition probability matrix by number of pixels of corresponding class in the later image. Transition probability matrix is represented in a text file that records the probability that each LULC category would change to any other category; while the transition area matrix, also represented in a text file records the number of pixels that are expected to change from one LULC type to the other over specified number of time units. The transition area matrix obtained from two time period was used as the basis for predicting the future LULC scenario.

The 1972 LULC image of Choudwar watershed was used as the base $\left(t_{1}\right)$ image while 1990 LULC map as the later $\left(t_{2}\right)$ image in Markov model to obtain the transition area matrix between 1972 and 1990 years for prediction of LULC in 1999 (table 7). The same image of 1990 was used as base image to obtain the transition area matrix between the year 1990 and 1999 for prediction of LULC of 2004 (table 6). The Markov's module in IDRISI created conditional probability images that report the probability of any LULC class to be found at a location. Even though, the transition probabilities were accurate on a per category basis, there was a salt and pepper effect in the output image, since this model did not consider the spatial distribution of the occurrences within each category (Soe and Le 2006).

We used CA-Markov model, wherein the transition area files were obtained from a Markov Chain analysis (using the MARKOV module) from 1999 and 2004. The weights were assigned to different drivers according to their importance, 
Table 8. A case of a pairwise comparison matrix for assessing the comparative importance of four factors to dense forest suitability.

\begin{tabular}{|c|c|c|c|c|}
\hline Factors & Population & $\begin{array}{c}\text { Residential } \\
\text { development }\end{array}$ & $\begin{array}{c}\text { Road-rail network } \\
\text { distance }\end{array}$ & $\begin{array}{l}\text { Slope } \\
\text { gradient }\end{array}$ \\
\hline Population & 1 & - & - & - \\
\hline $\begin{array}{l}\text { Residential } \\
\text { development }\end{array}$ & 1 & 1 & - & - \\
\hline $\begin{array}{l}\text { Road-rail network } \\
\text { distance }\end{array}$ & $1 / 2$ & $1 / 3$ & 1 & - \\
\hline Slope gradient & 3 & 4 & 5 & 1 \\
\hline
\end{tabular}

which addressed the past LULC trends for future prediction. The weights obtained were based on the importance of drivers like increase in population, residential development, distance to roadrail network; and settlement distance for increase or decrease in LULC class for which suitability map was obtained. Based on the weights allocated to drivers; suitability maps for each LULC was produced using MCE that establishes the inherent suitability of each pixel for each LULC type (table 8). The 2004 LULC map was used as the base map for estimating future LULC scenario for the year 2014 .

\section{Results and discussion}

\subsection{LULC dynamics}

The LULC change dynamics of Choudwar watershed was studied over more than three decades during the year 1972 to 2004. The results of LULC distribution for years 1972, 1990, 1999 and 2004 showed that forest area was the dominant land cover category (table 3 ). The overall classification accuracy for all the four time period maps was more than $90 \%$ (table 4). There has been a significant increasing trend for agriculture and settlement classes, whereas decreasing trend was observed for forest, wetland, marshy land, and fallow/barren lands (table 3 ). The change in agriculture, forest, wetland and marshy land classes during 1990 to 1999 was very high when compared with the change between 1972 and 1990, and 1999 and 2004 (table 5). The annual rate of increase from 1972 to 2004 in agriculture land, settlement was observed to be 181.96, 9.89 ha/year, respectively, while decrease in forest, wetland and marshy land were 91.22, 27.56 and 39.52 ha/year, respectively (table 5). The transition area matrix obtained (table 6), was used as the basis for future LULC change prediction for year 2004. Table 6 showed that 21,976 ha of forest area has the probability of converting into the agriculture class; while 1930, 2450 and 2523 ha area of wetland, marshy land and fallow and barren land have the probability to get converted into agricultural class from 1999 to 2004. The statistical values in table 6 showed the probable area that might convert from one class to another in 2004. The prediction results for 2004 on the basis of transition area matrix and past trends of both socio-economic and biophysical drivers resulted in $84.34 \%$ accuracy. The results of predicted LULC scenario showed drastic increase in agriculture and settlement area to 9677.79 and 1092.6 ha, respectively for the year 2014 (figures 6 and 7); decrease by forest, wetland and marshy land reduction to 6750, 125.82 and 281.29 ha, respectively.

\subsection{Prediction and validation}

In assessing LULC classification accuracy (table 4), it was observed that only water body, wetland and settlement provided the highest producer's accuracy (100\%) and user's accuracy (100\%) respectively. The forest and agriculture categories reached above $90 \%$ producer's accuracy and user's accuracy. The lowest producer's accuracy and user's accuracy $(75 \%)$ were produced by wetland and marshy land, respectively. It could be due to some overlapping between wetland and marshy land; while in fallow and barren land lower accuracy were observed due to seasonal variations of fallow and barren land in Mahanadi river course, which results in overprediction of fallow and barren land in 2004. In both the cases, the marshy land and fallow and barren land contributed to higher omission and commission errors (table 4). The changes in forest land, wetland and marshy land of watersheds during 1990 to 1999 were high; because east side of Choudwar watershed has been started developing with Kalinga industry production units in the early 1980. This resulted in drastic increase in agriculture area and settlement area; while reduction in forest, wetland and marshy land. In the prediction of future LULC scenarios, the expected area to change in transition area matrix was observed to be forest, wetland and marshy 

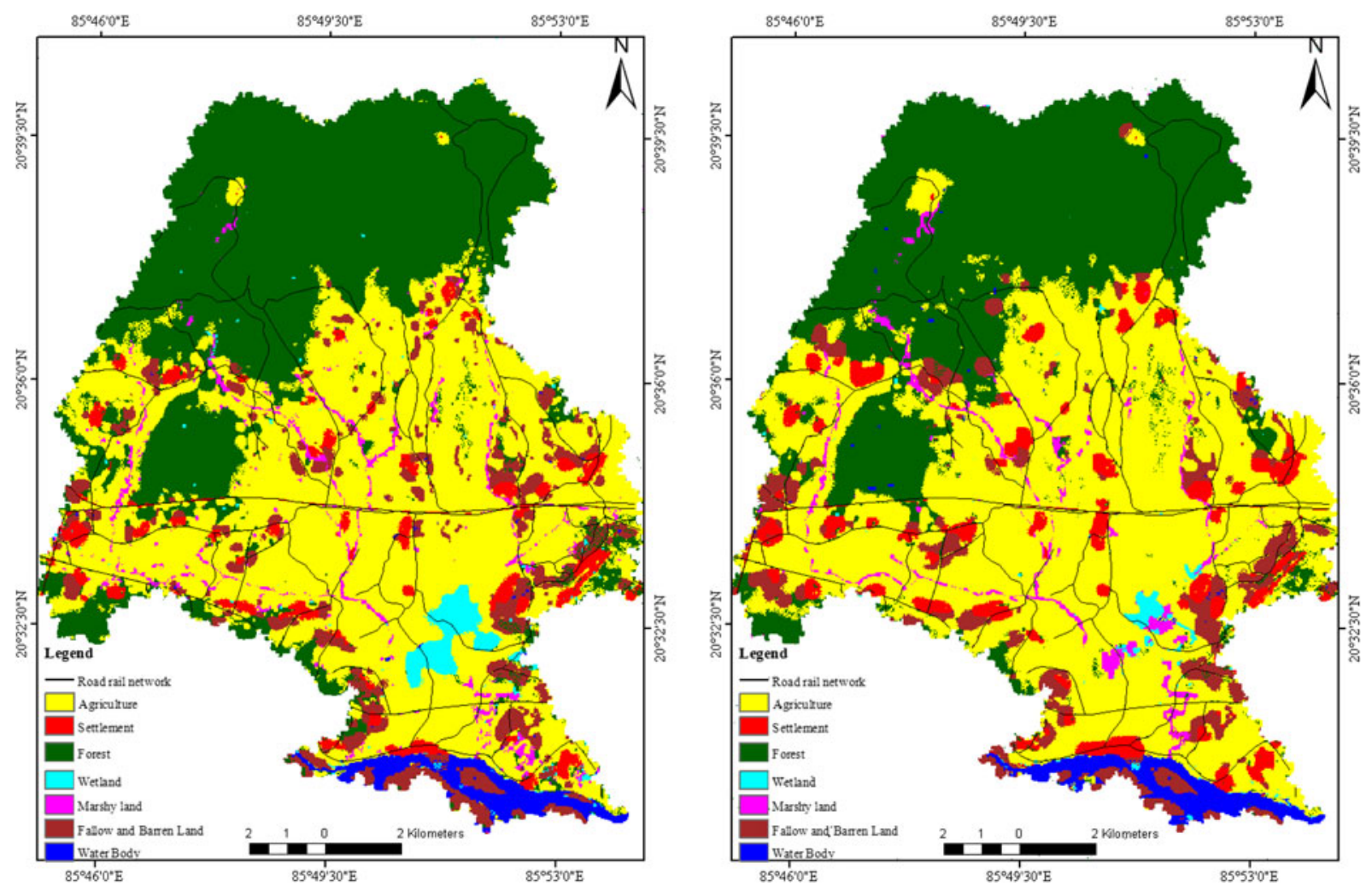

Figure 6. Predicted land use land cover map for years 2004 and 2014.

land. It could be due to agricultural expansion and involvement of both socio-economic and biophysical drivers. In multi-criteria decision-making

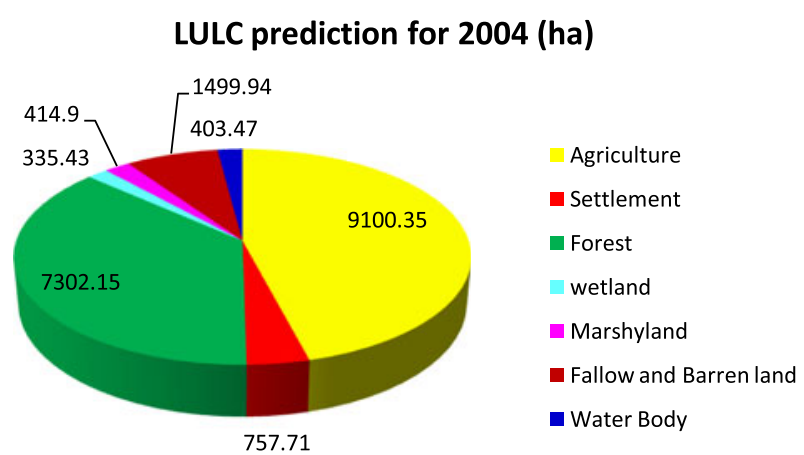

LULC prediction for 2014 (ha)

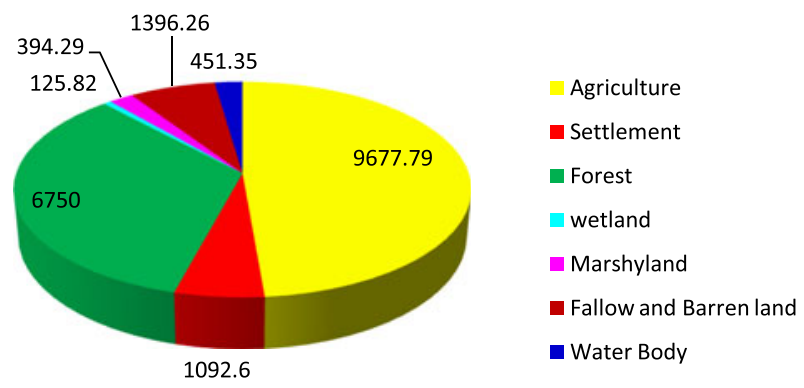

Figure 7. LULC area (ha) predicted scenarios for years 2004 and 2014. process, different biophysical and socio-economic drivers and their relative importance for change in watershed dynamics were considered. Our study investigated the human induced LULC patterns, land cover change and hydrologic change in LULC of watershed.

It was observed that agricultural expansion is the main driving force for change in forest, wetland and marshy land due to increase in population, residential development and proximity to rapidly developing Choudwar industrial area. While the change in fallow and barren land is due to conversion to settlement area, rapidly increasing village population in Choudwar watershed brought the pressure on existing agriculture land by replacing forest, wetland and marshy land. The statistics in table 5 provided the average annual rate of reduction from year 1972 to 2004 in the area of forest, wetland and marshy land is $91.22,-27.56$ and 39.52 ha per year. The area estimate provided the forest shrinkage; and this area became the main region where forest had been converted to agricultural land due to rapidly increasing population that brought the pressure on existing agriculture.

\subsection{Driving forces for major LULCC}

The settlement distance acting as proximate cause for deforestation due to human agriculture activity 
at the local level in Choudwar watershed, that intended change in LULC might have an impact on forest cover (Geist and Lambin 2002). The settlement distance played an important role in changes in LULC of Choudwar watershed by reduction in forest area and increase in new settlement area. This observation indicated that deforestation was the heaviest around the existing settlement area. Another proximate cause for change in LULC of watershed was distance from road-rail network. In this study, it was one of the drivers for change in forest area due to development on new settlements near the existing settlement. It was observed that the area within the 50 to $400 \mathrm{~m}$ distance from road-rail network was more suitable for new settlement, beyond the $400 \mathrm{~m}$ distance, the development and growth of new settlement reduced. The new settlements area increased from year 1990 to 2004 due to forest road network leading to increase in the agriculture area. The effects of road-rail network in Kapilas hill range resulted in fragmentation in the forests and created high contrast edges. The changes in landscape structure of Kapilas hill range forest are somewhat localized. The forest areas within the slope of $1^{\circ}-4^{\circ}$ mostly converted into the agricultural land while the areas having the slope between $5^{\circ}$ and $40^{\circ}$ had slowly converted into the agricultural land.

The prediction of LULC in watershed for the year 2014 was based on change in driver's impact with time and trend of LULC change from 1972 to 2004 and the weight applied for different factors in LULC prediction for years between 1999 and 2004. It was found that the integration of Markov model and Cellular Automata was effective for projecting future LULC scenario. It produced an overall accuracy of $88.5 \%$ when compared to predicted LULC map with the original satellite image using a stratified random approach. This is well above the acceptable limit of accuracy (Anderson et al. 1976). We performed accuracy assessment at the pixel level to compare classes at every pixel in an image with a reference source that considered all cells by directly comparing projected results against the classified output is also convincing $(76.26 \%)$. Hence the LULC change projected based on the four time period 1972, 1990, 1999 and 2004 LULC changes (more than three decades) and considering the impact of biophysical and socio-economic drivers in watershed showed the potential of modelling exercise for LULC change in the watershed.

\section{Conclusions}

This research work demonstrated utilization of remote sensing and GIS tools to analyse and model the LULC dynamics in a hydrological unit Choudwar watershed using CA-Markov model and predicted the future LULC scenario for years 2004 and 2014 with reasonably good accuracy. Future LULC change scenarios were addressed based on past three-decade old LULC change trends considering biophysical and socio-economic drivers. The overall accuracy of LULC change prediction for the year 2004 was $85.5 \%$; it showed that CAMarkov model can be used to analyze and capture future spatial-temporal LULC change dynamics of any watershed. Attempt was made to analyze the dynamics of watershed for the year 2014 as accurately as possible with seven LULC classes, in consideration with biophysical and socio-economic factors. The CA-Markov modelling approach described in this paper showed the influence of spatial relationships between biophysical and socio-economic drivers and LULC changes, which have to be taken into account to consider its impact on watershed. The area statistics (table 5) showed that agriculture and settlement expansion due to increase in population, residential development, industrial development were responsible for reduction in forest, wetland and marshy lands that are continuously changing the LULC dynamics of Choudwar watershed.

The usefulness of a holistic model that combines Markov and CA models for modelling, analyzing and predicting the changes in watershed LULC dynamics is demonstrated here. The main advantage of the modelling and prediction exercise is the suitability rating using multi-criteria decision-making. The LULC plausible states could be predicted by integrating biophysical and socioeconomic factors with the current LULC change in a watershed. The trends of increase in population, industrial development, agricultural expansion and forest degradation have led to increased LULCC. As per Soe and Le (2006), future LULCC models should be based on the change dynamics between several different periods of time instead of the change between only two time periods. In this study, the three time period changes were used to study the changes happened in more than three decades. The study revealed that agricultural expansion (triggered by increase in population, residential development and proximity to rapidly developing Choudwar industrial area) is the main driving force for loss of forest, wetland and marshy land in the watershed and has the potential to continue in future. The effects of connectivity, viz., road-rail network in Kapilas hill range has resulted in forest fragmentation and creation of high contrast edges. The forest of simpler terrain, i.e., within the slope of $1^{\circ}$ to $4^{\circ}$ was converted to agriculture land and threaten to climb beyond the slope range. 
This study has demonstrated some guidelines to foresee and examine possible future LULC growth in the watershed with different suitability rankings in multi-criteria decision-making in relation to different environmental, economic, planning and land development settings with effective use of the CA-Markov model. It would be helpful for planning and management of watershed resources also for restoring water availability, and improving ecological condition of watershed could be helped by the identification of areas suitable for water and soil conservation structures to restore the watershed dynamics. The LULC management prescriptions for the Choudwar watershed can include (i) construction of small water and soil conservation structures such as check dams, percolation ponds, irrigation tanks, etc., at gullies, (ii) participation of rural people and stakeholders to prevent further land degradation, and (iii) improvement in agriculture production following better agricultural practices and additional energy subsidy.

\section{Acknowledgements}

The evaluation version of IDRISI software obtained from Clarke's LAB is thankfully acknowledged. The financial support received from IIRS (ISRO), Dehradun under the umbrella of ISRO-GBP LULCC program for Indian river basins is thankfully acknowledged.

\section{References}

Ademiluyi I A and Otun W O 2009 Spatial decision support systems (SDSS) and sustainable development of the third world; J. Sustain. Dev. Africa 10(4) 200-217.

Anderson R, Hardy E E, Roach J T and Witmer R E 1976 A land use and land cover classification system for use with remote sensor data; USGS Professional Paper 964 (Sioux Falls, SD, Washington, DC USA), 28p.

Bishaw B 2001 Deforestation and land degradation in the Ethiopian highlands: A strategy for physical recovery; Northeast African Studies 8 7-25.

Bisht B S and Tiwari P C 1996 Land-use planning for sustainable resource development in Kumaun Lesser Himlalaya - a study of the Gomli watershed; Int. Sustain. Dev. World Ecol. 3 23-34.

Boerner R E J, Demers M N, Simpson J W, Artigas F J, Silva A and Berns L A 1996 Markov models of inertia and dynamic on two contiguous Ohio landscapes; Geogr. Anal. 28 56-66.

Clarke K C and Gaydos J 1998 Loose-coupling a cellular automaton model and GIS: Long-term urban growth prediction for San Francisco and Washington/Baltimore; Int. J. Geogr. Inf. Sci. 12 699-714.
Geist H and Lambin E F 2002 Proximate causes and underlying driving forces of tropical deforestation; BioScience 52 143-150.

Kallali H, Anane M, Jellali S and Tarhouni J 2006 GIS-based multi-criteria analysis for potential wastewater aquifer recharge sites; Desalination 215 111-119.

Lambin E F, Baulies X, Bockstael N, Fischer G, Krug T, Leemans R, Moran E F, Rindfuss R R, Sato Y, Skole D, Turner B L and Vogel C 1999 The change of land use in upriver regions of Yellow River, Land-use and land-cover change (LUCC): Implementation strategy, IGBP Report 48 IHDP Report No. 10, Stockholm, Bonn.

Lambin E F, Turner B L, Geist H J, Agbola S B, Angelsen A, Bruce J W, Coomes O T, Dirzo R, Fischer G, Folke C, George P S, Homewood K, Imbernon J, Leemans R, Li X B, Moran E F, Mortimore M, Ramakrishnan P S, Richards J F, Skanes H, Stefeen W, Stone G D, Svedin U, Veldkamp T A, Vogel C and Xu J C 2001 The causes of land-use and land-cover change: Moving beyond the myths; Global Environ. Change 11 261-269.

Liang G and Ding S 2006 Driving factors of forest landscape change in Yiluo River basin; J. Geogr. Sci. 16 $415-422$.

Malczewski J 1999 GIS and multicriteria decision analysis (New York: John Wiley and Sons Inc.).

Mather J R and Sdasyuk G V 1991 Global change: Geographical approaches (Tucson Arizona USA: University of Arizona Press).

National Research Council (NRC) Board on Sustainable Development, Policy Division, Committee on Global Change Research 1999, Global Environmental Change: Research Pathways for the Next Decade (Washington DC: National Academy Press).

Satty T L and Vargas L G 2001 Models, methods, concepts and applications of the analytic hierarchy process; Int. Ser. Oper. Res. Management Sci. 34b 1-352.

Soe W M and Le W 2006 Multicriteria decision approach for land use and land cover change using Markov chain analysis and a cellular automata approach; Canadian J. Rem. Sens. 32 390-404.

Sylvertown J, Hotlier S, Johnson J and Dale P 1992 Cellular automaton models of inter specific competition for space the effect of pattern on process; J. Ecol. 80 $527-534$.

Thomas H and Laurence H M 2006 Modeling and projecting land-use and land-cover changes with a cellular automaton in considering landscape trajectories: An improvement for simulation of plausible future states; $E A R S e L$ eProc. 5 63-76.

Turner II B L, Skole D, Sanderson S, Fischer G, Fresco $\mathrm{L}$ and Leemans R 1995 Land use land cover change science/research plan (IGBP Report No. 35 and HDP Report No. 7).

Wang X and Zhang C 2001 A dynamic modelling approach to simulating socioeconomic effects on landscape changes; Ecol. Model. 140 141-162.

Yang X and Lo C P 2002 Using a time series of satellite imagery to detect land use and cover changes in Atlanta, Georgia; Int. Remote Sens. 23 1775-1798.

Zhang X, Yu X, Wu S, Zhang M and Li J 2007 Response of land use/coverage change to hydrological dynamics at watershed scale in the Loess Plateau of China; Acta Ecologica Sinica 27(2) 414-423. 